Original Article

\title{
A COMPARATIVE STUDY OF THE PHYTOCHEMICALS, ANTIOXIDANT AND ANTIBACTERIAL POTENTIAL OF METHANOLIC EXTRACTS OF TRICHOSANTHES CUCUMERINA (L.) VAR. CUCUMERINA UNDER IN VITRO CULTURE AND NATURAL CONDITIONS
}

\author{
SUDHA BAI R. ${ }^{*}$, REMAKANTHAN A., HAREESH KUMAR H., ARYAKRISHNA U. K.
}

Post Graduate and Research Department of Botany, University College, Thiruvananthapuram-34, Kerala, India

Email: sudharvinayan@gmail.com

Received: 21 Sep 2017 Revised and Accepted: 22 Nov 2017

\begin{abstract}
Objective: To compare the phytochemicals, antioxidative capacity and antibacterial profile of methanolic extracts of callus and naturally propagated plant species-Trichosanthes cucumerina (L.) var. cucumerina and to optimize an ideal protocol for in vitro callus and shoot induction.

Methods: The sterilized seeds of Trichosanthes cucumerina (L.) var. cucumerina were inoculated in half Murashige and Skoog (MS) basal medium devoid of growth hormones to raise aseptic seedlings. Explants from aseptic seedlings used for callus induction in MS medium fortified with varying combinations of $\mathrm{N}^{6}$-Benzyl amino purine (BAP), 1-Naphthalene acetic acid (NAA) and 2,4-Dichlorophenoxy acetic acid (2,4-D). For in vitro soot induction, MS medium supplemented with different concentrations of 2,4-D, BAP and Kinetin-either alone or in combinations were employed. The callus harvested on $21^{\text {st }}$ and $45^{\text {th }}$ days were analyzed for a comparison of the influence of age of callus on the quantity of secondary metabolites. For a comparison with the naturally grown plant, all experiments were carried out with extracts from callus and wild plants. The antioxidant capacity of methanolic extracts was evaluated by 2,2-Diphenyl-1 Picryl Hydrazyl (DPPH) free radical scavenging assay and Ferric Reducing Antioxidant Power (FRAP) analysis. The antibacterial activity of were screened by the agar diffusion method using pathogenic bacteria such as Escherichia coli, Pseudomonas aeruginosa and Staphylococcus aureus and documented through measurement of the diameter of growth inhibition zone (IZ).
\end{abstract}

Results: The results on in vitro culture indicated that MS medium with BAP $(0.5 \mathrm{mg} / \mathrm{l})$ and 2,4-D $(1 \mathrm{mg} / \mathrm{l})$ was ideal for callus induction. For shoot induction, supplementation of MS medium with BAP- $0.5 \mathrm{mg} / \mathrm{l}, 2,4, \mathrm{D}-1.0 \mathrm{mg} / \mathrm{l}$ and Kinetin- $0.5 \mathrm{mg} / \mathrm{l}$ was found to be most favourable. Direct root induction from the callus was found to occur in medium fortified with BAP- $0.5 \mathrm{mg} / \mathrm{l}, 2,4, \mathrm{D}-0.5 \mathrm{mg} / \mathrm{l}$ and NAA-1.0 mg/l. The phytoconstituents quantified were alkaloids, flavonoids, tannins, phenols and terpenoids and their levels were higher in wild plant in comparison to callus. Naturally grown plant possesses higher free radical scavenging ability and ferric reducing power than callus. Results of antibacterial activity indicated that the Gram-positive strain (Staphylococcus aureus) was more sensitive than the Gram-negative bacteria (Escherichia coli and Pseudomonas aeruginosa). The highest antibacterial activity recorded for naturally propagated plant extract against $S$. aureus $(\mathrm{IZ}=13 \mathrm{~mm})$ and was quite comparable with standard antibiotic cephatoxim (IZ $=20 \mathrm{~mm}$ ) at $100 \mu \mathrm{g}$ concentration.

Conclusion: Results concluded that this overexploited medicinal plant with lesser seed longevity could be successfully propagated by in vitro methods. The phytoconstituents with antioxidative and antibacterial potential were more abundant in naturally propagated plants than undifferentiated callus tissue. The extracts are potent antibacterial agents.

Keywords: Trichosanthes cucumerina, In vitro culture, Antioxidant, Antibacterial, DPPH, FRAP

(C) 2018 The Authors. Published by Innovare Academic Sciences Pvt Ltd. This is an open access article under the CC BY license (http://creativecommons.org/licenses/by/4.0/) DOI: http://dx.doi.org/10.22159/ijpps.2018v10i1.22711

\section{INTRODUCTION}

The importance of herbal medicines in the treatment of acute and chronic ailments and their relevance as a safe and stable device is being highlighted in the present scenario [1] Trichosanthes cucumerina (L.) var. cucumerina, selected for the present study has a prominent place in alternative systems of medicine like Ayurveda and Siddha due to its various pharmacological activities like antidiabetic, hepatoprotective, cytotoxic, anti-inflammatory and larvicidal effects [2, 3].

All parts of this medicinal herb are extremely bitter and therefore the fruits are not consumed as a vegetable. Owing to bitterness, this species is commonly called "bitter snake gourd" This species is used exclusively as a medicine and is cultivated on a large scale by the tribals and stakeholders in eco-development committee (EDCs) under the Department of Forest and Wildlife in Kerala. Annual production of this plant by the EDCs of Kanthalloor and Marayoor (Idukki District) amounts to the range of 35-45 tonnes, for meeting the demand of the dried plant material by "Oushadhi" and "Kottakkal arya vaidya pharmacy" for the preparation of Ayurvedic formulations. Traditional literature like Charak Samhita mentions the protective role of the edible species Trichosanthes on important body organs like liver, spleen etc, many of which are now scientifically proven. Clinical investigation on peptic ulcer with the polyherbal formulation, where species of Trichosanthes is an integral part, has shown promising results. The genus is characterized by the abundance of an array of secondary metabolites like flavonoids, carotenoids, phenolics which render the plant pharmacologically and therapeutically active [4].

Generally, these secondary metabolites impart antioxidant property to medicinal plants and render them as natural agents to protect our body from the oxidative damage of biomolecules. Though free radicals can be effectively scavenged by synthetic antioxidant agents, natural antioxidants can always be considered as a better option in view of their limited side effects and higher safety [5, 6].

The increasing demand of this medicinal plant in large quantities for preparation of herbal medicines as well as the occasional failure of seed propagation due to lower seed longevity necessitates its mass multiplication. The present investigation was carried out to characterize the level of phytoconstituents, antioxidative potential and antimicrobial profile in samples from cultivated plants and under in vitro conditions. Attempts were carried out to establish an ideal protocol for callus and shoot induction to explore the possibility of mass propagation.

\section{MATERIALS AND METHODS}

Chemicals and reagents: source

MS medium, Nutrient agar, Nutrient broth, $\mathrm{N}^{6}-$ Benzyl amino purine (BAP), 1-Naphthalene acetic acid (NAA) and 2,4-Dichlorophenoxy 
acetic acid (2,4-D), Kinetin, DPPH (2,2-Diphenyl-1 Picryl Hydrazyl)HiMedia Laboratories Pvt. Ltd. Mumbai.

Mercuric chloride, acetic acid, trichloroacetic acid, hydrochloric acid, sulfuric acid, ferric cloride, sodium carbonate, potassium ferricyanide, potassium ferrocyanide-Sisco research Laboratory Pvt. Ltd. Mumbai.

Methanol, chloroform, Folin's reagent, magnesium turnings, aluminium chloride, gallic acid, tannic acid, ascorbic acid-sd fine chemicals Ltd. Mumbai.

Sodium nitrite, sodium hydroxide, sodium hydrogen phosphate (mono and dibasic)-Qualigens fine chemicals, Mumbai

\section{In vitro culture-establishment of aseptic seedlings as explant source}

The seeds were washed in running tap water for few min and then washed repeatedly in double distilled water. Under aseptic conditions, the seed coats were removed and the dehusked seeds surface sterilized with 70\% ethanol for one min and then rinsed 3-5 times in sterile double distilled water followed by a seven min treatment with $0.1 \%(\mathrm{w} / \mathrm{v})$ mercuric chloride and rinsed 5 times in sterile double distilled water. The sterilized seeds were then inoculated in $1 / 2$ MS basal medium. About 6-10 seeds were cultured per bottle and five replicates were taken for each combination of growth regulators in $50 \mathrm{ml}$ of the medium for raising in vitro sterile seedlings as explant source.

\section{Callus induction}

Different explants including cotyledon, epicotyl and hypocotyl were excised from the in vitro raised seedlings (fig. 1A-B) on $14^{\text {th }}$ day and inoculated in MS media supplemented with plant growth regulators in order to study the in vitro response and callus formation. Segments of each type of explants were inoculated in MS medium supplemented with different concentrations and combinations of BAP $(0.5 \mathrm{mg} / \mathrm{l})$, NAA $(1 \mathrm{mg} / \mathrm{l}), 2,4 \mathrm{D}(0.5-2 \mathrm{mg} / \mathrm{l})$ for callus induction. Six different combinations of the three growth regulators were compared for their frequency of callus formation. After inoculation, the culture bottles were sealed properly and placed in the culture room maintained at $25 \pm 2{ }^{\circ} \mathrm{C}$ with 2500 lux of light intensity provided by cool, white fluorescent tubes.

\section{Subculture of callus and nodal explants for shoot induction}

Callus formed were sub-cultured after 20-25 d of inoculation. Subculturing was carried out in $1 / 2$ strength MS medium supplemented with different concentrations and combinations of BAP $(0.5 \mathrm{mg} / \mathrm{l})$ $2,4 \mathrm{D}(0.5 \mathrm{mg} / \mathrm{l})$ and kinetin $(0.5 \mathrm{mg} / \mathrm{l})$. Direct shoot development was also documented for the nodal explants dissected out from aseptically grown seedlings using the same media compositions.

\section{Preparation of extracts for phytochemical analysis}

The callus tissues were harvested as two sets of samples-21 d old calli and $45 \mathrm{~d}$ old calli to carry out a comparative evaluation of maturity level of callus on quantitative variation in secondary metabolites. $20 \mathrm{~g}$ of callus tissue was dried at $40^{\circ} \mathrm{C}$ in an oven until constant weight, powdered and $5 \mathrm{~g}$ of the dry powdered callus was extracted with $20 \mathrm{ml} 90 \%$ methanol. The plants grown in the experimental garden of the college were harvested during flowering phase, washed, shade dried until constant weight and powdered. About $25 \mathrm{gm}$ of dried powder was extracted in $100 \mathrm{ml} 90 \%$ methanol. These samples, suspended in methanol were placed in a water bath at $45^{\circ} \mathrm{C}$ for $10 \mathrm{~h}$ and then placed in a gyratory shaker at $120 \mathrm{rpm}$ for $48 \mathrm{~h}$. Each type of extract was filtered using Whatman No.1 filter paper, dried to attain constant weight and the yield and quality of extract were recorded. A stock solution $(\mathrm{mg} / \mathrm{ml})$ of extract from the sample was prepared using methanol. These extracts were analyzed quantitatively for the presence of various phytochemicals. Phytochemical examinations were carried out for the extracts of callus and naturally propagated Trichosanthes cucumerina (L.) var. cucumerina as per the standard methods.

\section{Quantitative analysis of phytochemicals}

Determination of alkaloids-For estimation of alkaloids, $5 \mathrm{~g}$ of each sample was blended with $200 \mathrm{ml}$ of $20 \%$ acetic acid and kept for 40 h. This mixture was filtered and the volume was reduced to one quarter using a water bath. To this sample, concentrated ammonium hydroxide was added dropwise until the precipitation was complete. The solution was allowed to settle and the precipitate was collected by filtration and weighed [7].

The percentage of total alkaloid content was calculated as:

$$
\text { Percentage of total alkaloids }(\%)=\frac{\text { weight of residue }}{\text { weight of sample taken }} \times 100
$$

\section{Determination of total phenolics}

Phenolic content was determined by mixing $3.9 \mathrm{ml}$ of distilled water and $0.5 \mathrm{ml}$ of Folin's reagent with $0.1 \mathrm{ml}$ of the extract. The solution was incubated at room temperature for $3 \mathrm{~min}$ and then added $2 \mathrm{ml}$ of $20 \%(\mathrm{w} / \mathrm{v})$ sodium carbonate solution to the mixture. The solution was kept in boiling water bath for $1 \mathrm{~min}$, cooled and the absorbance recorded at $650 \mathrm{~nm}$. Gallic acid standard was used to express the total phenol content [8].

\section{Determination of total flavonoid}

The content of total flavonoids was measured spectrophotometrically by using the aluminium chloride colourimetric assay [9]. A total of $1 \mathrm{ml}$ of plant extracts were diluted with $200 \mu \mathrm{l}$ of distilled water followed by the addition of $150 \mu \mathrm{l}$ of sodium nitrite $(5 \%)$ solution. This mixture was incubated for $5 \mathrm{~min}$ and then $150 \mu \mathrm{l}$ of aluminium chloride $(10 \%)$ solution was added and allowed to stand for $6 \mathrm{~min}$. Then $2 \mathrm{ml}$ of sodium hydroxide (4\%) solution was added and made up to $5 \mathrm{ml}$ with distilled water. The mixture was shaken well and left for $15 \mathrm{~min}$ at room temperature. The absorbance was measured at $510 \mathrm{~nm}$.

\section{Determination of total tannin}

\section{a) Reagents}

Coloring agent: Dissolve $1.6221 \mathrm{~g}$ of ferric chloride $(0.1 \mathrm{M}), 0.9 \mathrm{ml}$ of hydrochloric acid $(0.1 \mathrm{~N})$ and $263.4 \mathrm{mg}$ of potassium ferrocyanide $(0.008 \mathrm{M})$ in $100 \mathrm{ml}$ of water.

Working standard solution: A stock solution of $100 \mu \mathrm{g} / \mathrm{ml}$ tannic acid was prepared and used as a standard.

b) Procedure: The powdered samples, $1 \mathrm{~g}$ each were boiled with $100 \mathrm{ml}$ of water for $30 \mathrm{~min}$, cooled and filtered through a Whatman no.1 filter paper and made up to $100 \mathrm{ml}$ with distilled water. Added $0.5 \mathrm{ml}$ of coloring agent the blue colour developed was measured at $760 \mathrm{~nm}$ against reagent blank after $30 \mathrm{~min}$ at room temperature. Added colouring reagent to the standard (tannic acid at concentration ranges $-20-100 \mu \mathrm{g} / \mathrm{ml}$ ) and calculated the amount of tannic acid equivalent. The tannin content of the samples is expressed as mg of tannic acid equivalent (TE)/g of the dried sample [10].

\section{Determination of total terpenoid}

To estimate total terpenoid content in the plant extract, $1 \mathrm{~g}$ of each powder was blended in $10 \mathrm{ml}$ methanol and $15 \mathrm{ml}$ water. The mixture was shaken well and centrifuged at $10000 \mathrm{rpm}$ for $10 \mathrm{~min}$. The filtrate was taken. To $1 \mathrm{ml}$ of extracts, $2 \mathrm{ml}$ of chloroform followed by $3 \mathrm{ml}$ of concentrated sulphuric acid was added. Formation reddish brown colour indicated the presence of terpenoids. Terpenoids estimated by reading the absorbance at 538 nm against blank of $95 \%$ methanol.

\section{In vitro antioxidant assay}

\section{(a) DPPH (2, 2-diphenyl-l-picrylhydrazyl) radical scavenging assay}

The antioxidant activity of the extracts was estimated using the DPPH radical scavenging protocol [11]. DPPH solution $(0.004 \%$ $\mathrm{w} / \mathrm{v}$ ) was prepared in methanol. A stock solution of DPPH solution$0.004 \%(\mathrm{w} / \mathrm{v})$ prepared in $95 \%$ methanol. Methanolic extract and standard ascorbic acid were prepared in the concentration of $\mathrm{mg} / \mathrm{ml}$. From stock (methanolic extract and ascorbic acid) solution 1 $\mathrm{ml}, 2 \mathrm{ml}, 3 \mathrm{ml}, 4 \mathrm{ml}$ and $5 \mathrm{ml}$ of this solution were taken in five test tubes respectively. With the same solvent made the final volume of 
each test tube up to $1 \mathrm{ml}$ whose concentration was then $100 \mu \mathrm{g} / \mathrm{ml}$, $200 \mu \mathrm{g} / \mathrm{ml}, 300 \mu \mathrm{g} / \mathrm{ml}, 400 \mu \mathrm{g} / \mathrm{ml}, 500 \mu \mathrm{g} / \mathrm{ml}$ respectively. To each sample added $2 \mathrm{ml}$ of freshly prepared DPPH solution. The reaction mixture was incubated in the dark for $30 \mathrm{~min}$ and the optical density was recorded at $517 \mathrm{~nm}$ against the blank. For the control, $2 \mathrm{ml}$ of DPPH solution in methanol was mixed with $1 \mathrm{ml}$ of methanol and the optical density of the solution was recorded after $30 \mathrm{~min}$. The assay was carried out in triplicates. The decrease in optical density of DPPH on the addition of test samples in relation to the control was used to calculate the antioxidant activity, as percentage inhibition of DPPH radical. The capability of scavenging DPPH radical was calculated using the following equation.

$$
\text { DPPH scavenged }(\%)=\frac{\left(\mathrm{A}^{\prime} \text { control'- } \mathrm{A} \text { 'test }{ }^{\prime}\right)}{\mathrm{A} \text { control }} \times 100
$$

Where A 'control' is the absorbance of the control reaction and A 'test' is the absorbance of the sample of the extracts.

\section{(b) Ferric reducing antioxidant power (FRAP assay)}

Methanolic extracts of callus and plant were compared for their Ferric reducing power [12], using ascorbic acid as standard.

Test samples $(1 \mathrm{ml})$ in different concentrations $(100-500 \mu \mathrm{g} / \mathrm{ml})$ were mixed with $1 \mathrm{ml}$ of $0.2 \mathrm{M}$ sodium phosphate buffer (pH 6.6) and $1 \mathrm{ml}$ of $1 \%$ potassium ferricyanide in separate test tubes. The reaction mixtures were incubated in a water bath at $50{ }^{\circ} \mathrm{C}$ for 20 min, followed by addition of $1 \mathrm{ml}$ of $10 \%$ trichloroacetic acid. The mixtures were then centrifuged for $10 \mathrm{~min}$ at room temperature. The supernatant obtained $(1 \mathrm{ml})$ was added with $1 \mathrm{ml}$ of deionized water and $200 \mu$ of $0.1 \% \mathrm{FeCl}_{3}$. The blank was prepared in the same manner as the samples except that $1 \%$ potassium ferricyanide was replaced by distilled water. The absorbance of the reaction mixture was measured at $700 \mathrm{~nm}$. The reducing power was expressed as an increase in absorbance after blank subtraction.

\section{Antibacterial activity}

\section{Microbial strains}

The microorganisms used for the evaluation of antibacterial activity were two Gram-negative strains-Escherichia coli and Pseudomonas aeruginosa and one Gram-positive strainStaphylococcus aureus. All the organisms used in this study were clinical isolates obtained from Department of Microbiology, Medical College, Thiruvananthapuram.

\section{Culture medium and inoculation}

The stock cultures of microorganisms used in this study were maintained in nutrient agar slants at $4{ }^{\circ} \mathrm{C}$. Inoculum was prepared by suspending a loopful of bacterial culture from stock slant into $25 \mathrm{ml}$ of sterilized nutrient broth (prepared by dissolving $5 \mathrm{~g}$ Nutrient broth-readymade Himedia in $200 \mathrm{ml}$ distilled water), maintained in a gyratory shaker at $120 \mathrm{rpm}$ for $48 \mathrm{~h}$ to get uniform growth of bacteria.

\section{Medium for culture plate}

Nutrient agar (11.2g) was dissolved in $400 \mathrm{ml}$ distilled water, as per the instruction provided by the suppliers (Himedia) and heated gently to dissolve the powder completely. The sterilized nutrient agar medium was cooled to $45-50{ }^{\circ} \mathrm{C}$ and $30 \mathrm{ml}$ was poured into each culture plate. The plates were examined after $24 \mathrm{~h}$ for any contamination before carrying out the antibacterial analysis of the extracts.

\section{Preparation of antibiotic (positive control)}

The positive control employed for comparison of the antibacterial potential of the extracts was the standard cefotaxim. A stock solution $(\mathrm{mg} / \mathrm{ml})$ of the standard was prepared in saline solution and $0.1 \mathrm{ml}$ aliquot $(100 \mu \mathrm{g} / \mathrm{ml})$ was used to test bacterial sensitivity.

\section{Antibacterial analysis}

Determination of antibacterial potential of the extracts was carried out using agar well diffusion method [13]. The solidified nutrient agar in the Petri plates was inoculated by dispensing $0.2 \mathrm{ml}$ of the inoculum using a sterilized pipetting device and spread evenly with sterile cotton swabs. Four wells were prepared in each plate with the help of a sterile cork-borer of $5 \mathrm{~mm}$ diameter. Each extract was diluted to obtain the concentration $1 \mathrm{mg} / \mathrm{ml}$. Each diluted extract $(0.1 \mathrm{ml}$; concentration $-100 \mu \mathrm{g} / \mathrm{ml})$ was introduced in each well. Wells introduced with $0.1 \mathrm{ml}$ of methanol and $0.1 \mathrm{ml}$ of cephotaxim $(100 \mu \mathrm{g})$ served as negative and positive controls respectively. All the plates containing loaded wells were incubated for $24 \mathrm{~h}$ at $37^{\circ} \mathrm{C}$. After the incubation period zone of inhibition for each concentration of extract and antibiotic cefotaxime were measured by calculating the difference between the diameter of cork-borer and diameter of clear zone [14]. The same method of experiment was carried out in the triplicates and the mean values were reported for the final consideration.

\section{RESULTS}

\section{In vitro culture for callus and shoot induction}

In the present study, several different combinations of auxins were tested for initiation of friable and vigorous growing callus from hypocotyl, epicotyl and cotyledonary explants. Various auxin concentrations used in this study produced different types of callus morphology and callus induction percentages. When cultured on a medium with varying concentrations of BAP alone, the explants produced no callus. In contrast, in MS medium supplemented with auxin, cultured explants were swollen after five days of inoculation and callus emerged at the cut edges within $10 \mathrm{~d}$ of culture (fig. 1C-F). MS with $1 \mathrm{mg} / \mathrm{l}$ 2,4-D in combination with $0.5 \mathrm{mg} / \mathrm{l} \mathrm{BAP}$ was the most effective medium for friable callus induction from cotyledons and the highest frequency recorded was $83.33 \%$ (table 1). Substitutions with other auxins (NAA) or increasing or decreasing the concentration of 2,4-D resulted in a reduced percentage of callusing (table 1).

The calli were white, nodular with roots at $0.5 \mathrm{mg} / \mathrm{l} 2,4-\mathrm{D}$ (fig. $2 \mathrm{~A}$ ) and relatively brownish with a dry friable appearance at $2 \mathrm{mg} / \mathrm{l}$ 2,4-D (fig. 2B). However, when MS in combination with higher or lower concentrations of NAA was used, the callus morphology and callus induction percentages differed but induction occurred with moderate frequency- 42.85 to $75 \%$ (table 1 ). The study concluded that the best result on callus induction could be recorded for cotyledon explants cultured on MS medium with BAP $(0.5 \mathrm{mg} / \mathrm{l})$ and 2,4-D $(1 \mathrm{mg} / \mathrm{l})$.

Table 1: Percentage of callus induction in different growth hormone concentration

\begin{tabular}{lllll}
\hline \multirow{2}{*}{ S. No. } & \multicolumn{2}{l}{ Growth hormone conc (mg/l) } & Percentage of callus induction \\
\cline { 2 - 4 } & BAP & $\mathbf{2 , 4 - D}$ & NAA & \\
\hline 1 & 0.5 & 0.5 & - & 25.28 \\
2 & 0.5 & 1 & - & 83.33 \\
3 & 0.5 & 1.5 & - & 50.27 \\
4 & 0.5 & 2 & 1 & 71.42 \\
5 & 0.5 & 1 & 1 & 75.08 \\
6 & 0.5 & 1.5 & 1 & 42.85 \\
7 & 0.5 & 2 & 1 & \\
\hline
\end{tabular}

(N6-Benzyl amino purine (BAP), 1-Naphthalene acetic acid (NAA), 2,4-Dichlorophenoxy acetic acid (2,4-D) 
One of the objectives of this study was to investigate the effect of growth regulators in shoot induction from the callus and nodal explants of Trichosanthes cucumerina (L.) var. cucumerina. Direct root formation (fig. 2A and 2B) from callus was detected in MS medium containing BAP-0.5 mg/l, 2,4,D-0.5 mg/l and NAA-1 mg/l. As depicted in fig. $2 \mathrm{C}$ and 2D, direct shoot initiation was monitored from the callus in MS medium with hormone combination (BAP$0.5 \mathrm{mg} / \mathrm{l}, 2,4, \mathrm{D}-1.5 \mathrm{mg} / \mathrm{l})$ along with kinetin $(0.5 \mathrm{mg} / \mathrm{l})$. Nodal explant of T. cucumerina showed direct shoot induction (fig. 2E and $2 \mathrm{~F}$ ) with hormone supplementation in the range (BAP-0.25 $\mathrm{mg} / \mathrm{l}$ and NAA- $0.5 \mathrm{mg} / \mathrm{l}$ ). The differential responses indicated by various explants in MS media with the best combinations of hormones are summarized in table 2 . The results suggested that in vitro shoot differentiation and plant regeneration can be effectively carried out for mass propagation of this valuable medicinal plant.

Table 2: The explant response to different growth hormone combinations

\begin{tabular}{ll}
\hline In vitro response & Hormone combination (mg/l) \\
\hline Maximum callus induction & BAP-0.5, 2,4,D-1 \\
Direct root induction from the callus & BAP-0.5, 2,4,D-0.5, NAA-1 \\
Direct shoot induction from the callus & BAP-0.5, 2,4,D-1.0, Kinetin-0.5 \\
Direct shoot induction from nodal explant & BAP-0.25, NAA-0.5 \\
\hline
\end{tabular}

( ${ }^{6}$-Benzyl amino purine (BAP), 1-Naphthalene acetic acid (NAA), 2,4-Dichlorophenoxy acetic acid (2,4-D)

\section{Quantitative phytochemical analysis}

The results of quantitative estimation of various phytoconstituents in callus and in vivo plant samples are illustrated in table 3 . Alkaloids and tannins were absent in callus extract but were substantially high in the naturally grown plant. Both callus and the wild grown plant contained flavonoids, phenolics and terpenoids.

In general, all phytoconstituents were present in higher levels in the extract of in vivo plant sample.

Table 3: Quantitative analysis of phytochemicals in methanolic extracts of Trichosanthes cucumerina (L) var. cucumerina

\begin{tabular}{llllll}
\hline Source of extract & Alkaloids (mg/g) & Flavonoids (mg/g) & Phenols (mg/g) & Tannins (mg/g) & Terpenoids (mg/g) \\
\hline Callus (21 d) & 0 & 0.052 & 8.09 & 0 & 0.051 \\
Callus (45 d) & 0 & 0.306 & 9.07 & 0 & 0.177 \\
Wild plant & 9.75 & 1.52 & 13.04 & 2.54 & 1.08 \\
\hline
\end{tabular}

The effects of age of callus were also investigated to determine the impact of cellular ageing on the level of phytochemicals under in vitro conditions. A Comparative study between fresh friable callus $(21 \mathrm{~d}$

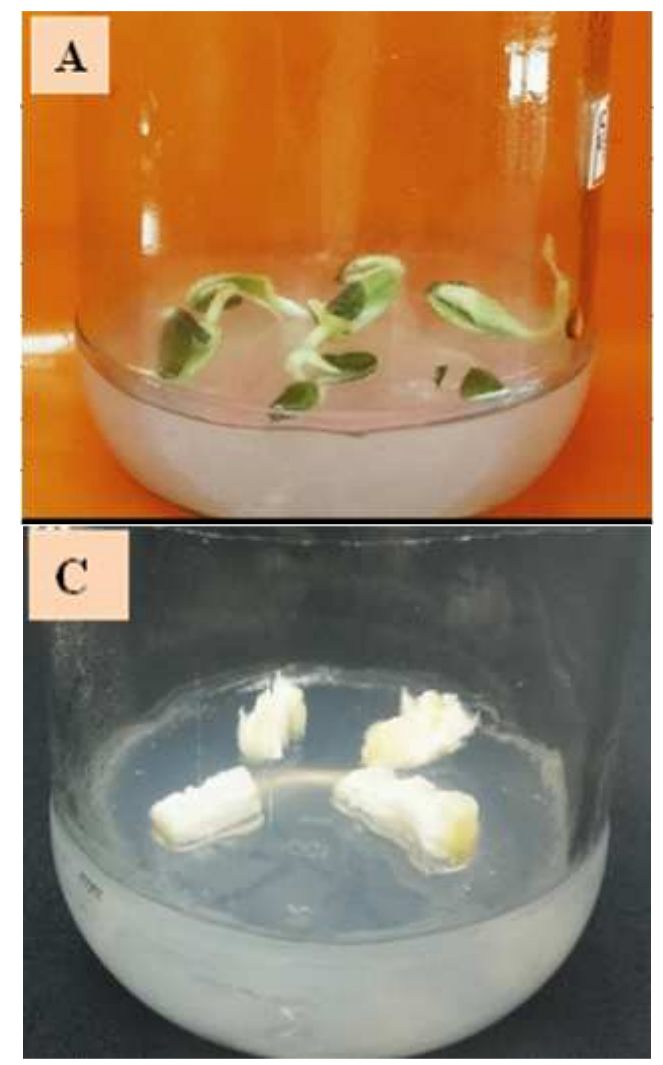

old) and aged callus ( $45 \mathrm{~d}$ old) induced in MS medium supplemented with BAP $(0.5 \mathrm{mg} / \mathrm{l}$ and 2 , 4-D $(1 \mathrm{mg} / \mathrm{l})$ revealed that the level of flavonoids, phenolics and terpenoids increase with callus ageing.

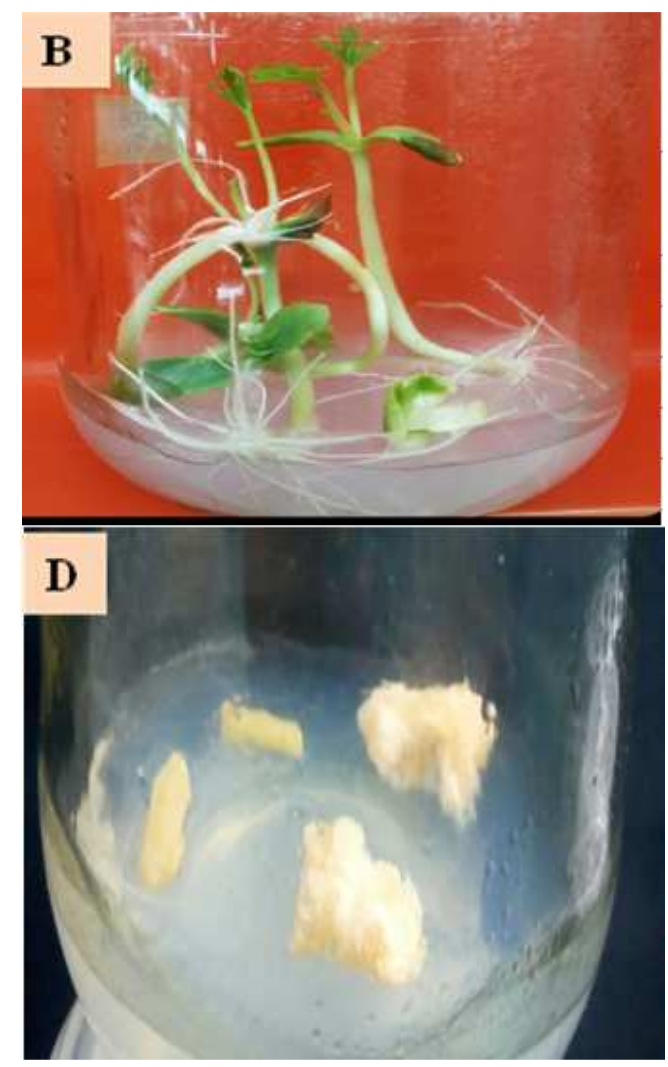



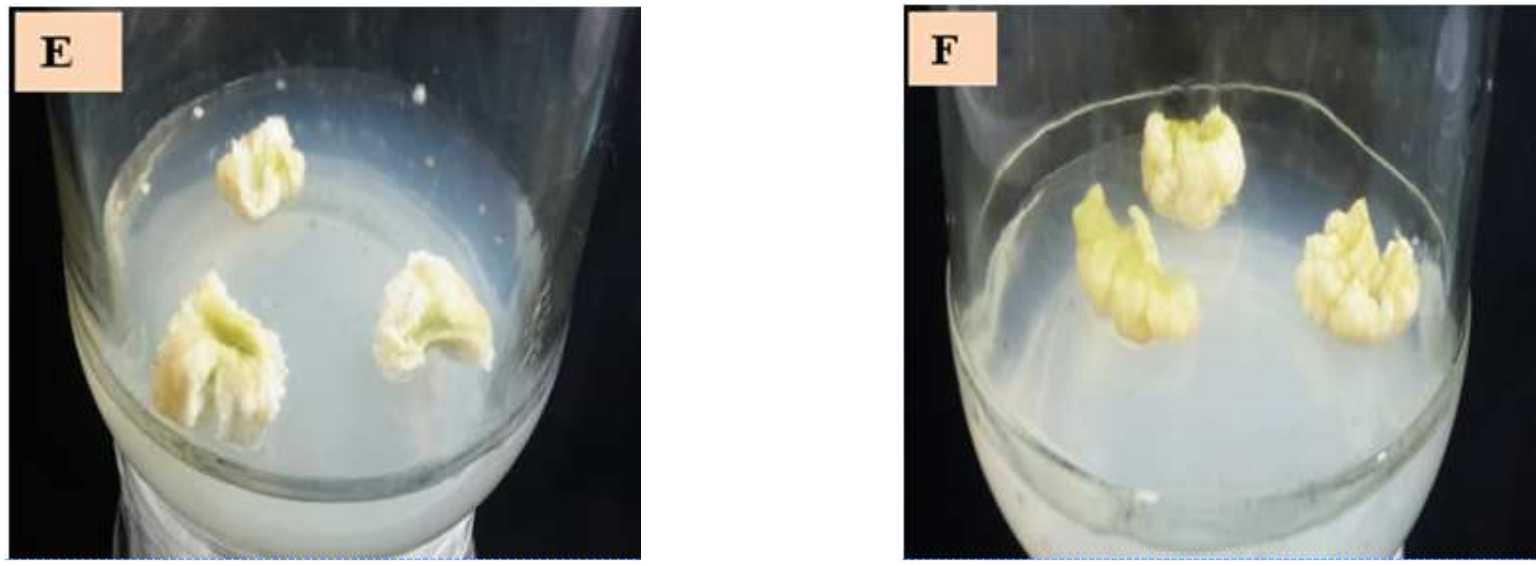

Fig. 1: In vitro seed germination and callus induction, A-Germination B-aseptic seedlings C-hypocotyl explants, D-epicotyl explant Ecotyledon explant F-Leaf explants
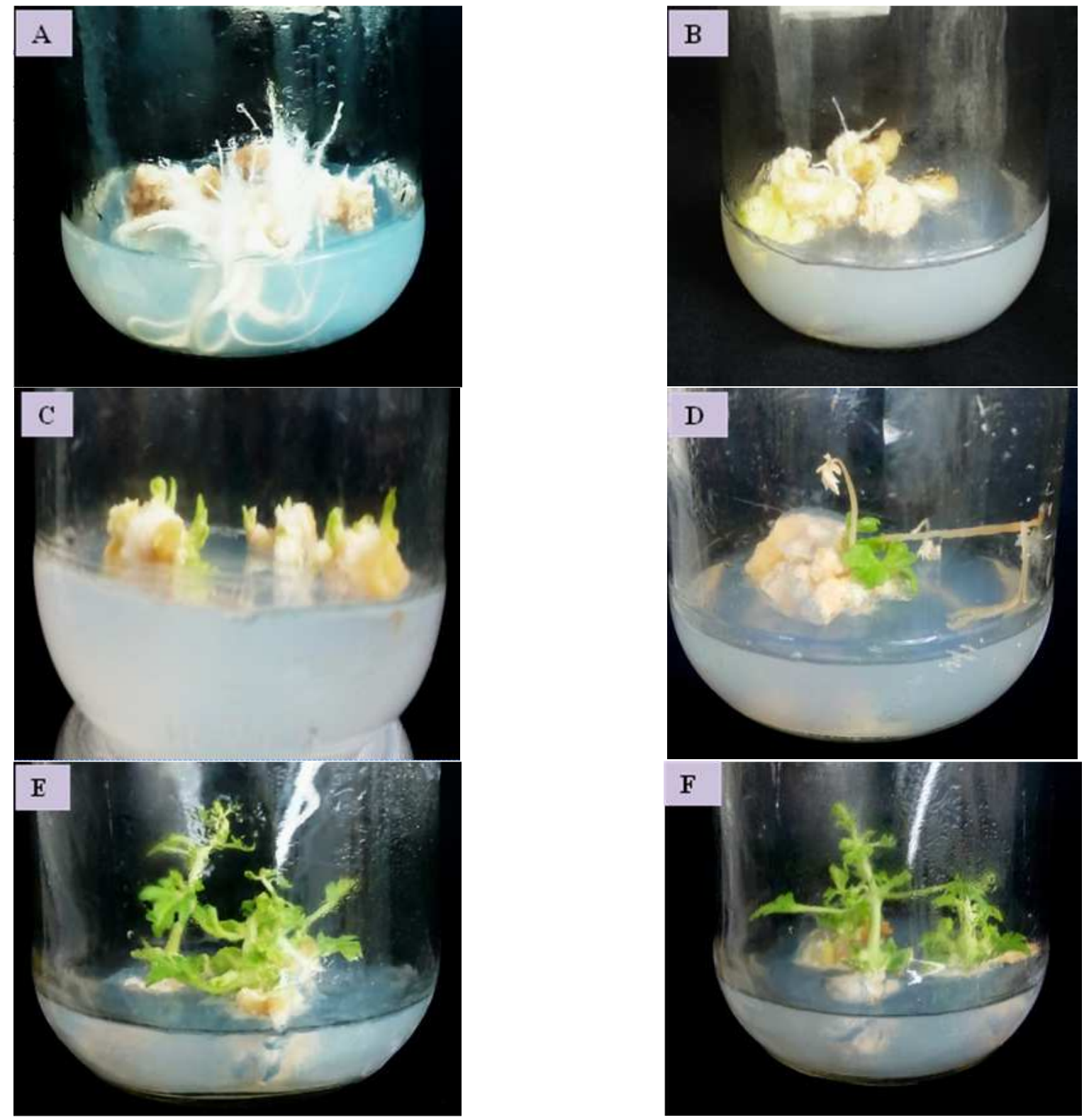

Fig. 2: Direct root induction and shoot induction, A-Root induction from hypocotyl explant: B-root induction from cotyledonary explants, (MS with BAP-0.5 mg/l; 2,4,D-0.5 mg/l; NAA-1 mg/l), CandD-Stages of shoot initiation from callus (MS with BAP-0.5 mg/l; 2,4,D-1.5 mg/l; Kinetin-0. mg/l), EandF-Shoot initiation and callusing from nodal explant (MS with BAP-0.25 mg/l; NAA-0.5 mg/l) 


\section{Antioxidant activity}

\section{(a) DPPH (2, 2-diphenyl-1-picryl hydrazyl) radical scavenging assay}

The results of free radical scavenging ability of a methanolic extract of the plant material and callus at different concentration are illustrated in the table 4 . It is expressed as the percentage of inhibition of free radicals by antioxidants present in the extract. The results on DPPH scavenging activity suggested that there is an increase in the percentage of radical scavenging activity with an increase in the concentration of the extracts.

Among the extracts, the highest scavenging activity at $500 \mu \mathrm{g} / \mathrm{ml}$ extract concentration was recorded $(91.85 \%)$ for extract of in vivo plant sample. For callus extract, the maximum scavenging activity recorded was $63.48 \%$.

Table 4: DPPH radical scavenging potential of the extracts

\begin{tabular}{|c|c|c|c|c|c|c|}
\hline $\begin{array}{l}\text { Conc } \\
(\mu \mathrm{g} / \mathrm{ml})\end{array}$ & Standard (Ascorbic acid) & $\begin{array}{l}\mathrm{IC}_{50} * \\
\text { (standard) }\end{array}$ & $\begin{array}{l}\text { Wild plant } \\
\text { (in vivo) }\end{array}$ & $\begin{array}{l}\mathrm{IC}_{50} * * \\
(\text { in vivo) }\end{array}$ & Callus & $\mathrm{IC}_{50} * *$ (callus) \\
\hline 100 & $28.97+0.17$ & $207.90 \mu \mathrm{g}$ & $20.85+0.05$ & $393.82 \mu \mathrm{g}$ & $14.61+0.07$ & $355.23 \mu \mathrm{g}$ \\
\hline 200 & $48.10+0.21$ & & $34.86+0.18$ & & $22.98+0.16$ & \\
\hline 300 & $71.94+0.06$ & & $49.83+0.24$ & & $38.91+0.07$ & \\
\hline 400 & $87.76+0.18$ & & $73.35+0.06$ & & $56.30+0.22$ & \\
\hline 500 & $98.44+0.08$ & & $91.85+0.12$ & & $63.48+0.15$ & \\
\hline
\end{tabular}

*Each value represented as mean+SD $(n=3)^{* *}$-IC $\mathrm{C}_{50}$-Half maximal inhibitory concentration

\section{Ferric reducing antioxidant power (FRAP) assay}

In the FRAP assay, a linear increase in reducing power was observed over the concentration range $100-500 \mu \mathrm{g} / \mathrm{ml}$. A comparison of the ferric reducing power in relation to standard-ascorbic acid is summarized table 5. A linear progression in reducing ability over a concentration range of $100-500 \mu \mathrm{g} / \mathrm{ml}$ was recorded in FRAP assay.
Extracts from naturally grown T. cucumerina indicated ferric reducing power either greater than or at comparable levels with the standard ascorbic acid. The reducing capacity of callus was lesser than the wild plant. In conclusion, the present study demonstrated that extracts from tissues of both in vitro (callus) and in vivo (wild plant) samples of Trichosanthes possesses strong antioxidant activity.

Table 5: Ferric reducing power of extracts-influence of extract concentration

\begin{tabular}{llll}
\hline $\begin{array}{l}\text { Conc } \\
(\mu \mathrm{g} / \mathrm{ml})\end{array}$ & Absorbance (700 nm) & Standard (ascorbic acid) \\
\cline { 2 - 4 } & Callus & $0.004+0.033$ & $0.089+0.017$ \\
200 & $0.127+0.065$ & $0.121+0.009$ & $0.167+0.004$ \\
300 & $0.223+0.042$ & $0.235+0.014$ & $0.253+0.014$ \\
400 & $0.257+0.008$ & $0.311+0.008$ & $0.321+0.012$ \\
500 & $0.271+0.015$ & $0.456+0.033$ & $0.484+0.024$ \\
\hline
\end{tabular}

*Each value represented as mean+SD $(\mathrm{n}=3)$

\section{Antibacterial activity}

The methanolic extract of Trichosanthes cucumerina (L.) var. cucumerina showed moderate antibacterial activity against all the microorganisms tested (table 6). The methanolic extract of the wild plant showed appreciable activity against Staphylococcus aureus (inhibition zone-13 mm/100 $\mathrm{\mu g} / \mathrm{ml}$ ) and Escherichia coli (11 $\mathrm{mm} / 100 \mu \mathrm{g} / \mathrm{ml}$ ). The bacterial sensitivity to the plant extract is quite comparable with that of the standard antibiotic cephotaxim $(20$ $\mathrm{mm} / 100 \mu \mathrm{g} / \mathrm{ml})$.

Table 6: Antibacterial activity of Trichosanthes cucumerina (L) var. cucumerina against different strains of bacteria

\begin{tabular}{llll}
\hline Type of extract & \multicolumn{2}{l}{ Diameter of Inhibition Zone $(\mathbf{m m})$} & E. coli \\
\cline { 2 - 4 } & S. aureus & P. aeruginosa & $4.00+0.00$ \\
\hline Callus & $5.03+0.05$ & $4.8+0.28$ & $11.16+0.28$ \\
Wild plant & $13.00+1.00$ & $4.00+0.06$ & $13.00+0.00$ \\
Positive control & $20.00+1.00$ & $11.00+0.05$ & $2.03+0.05$ \\
Negative control & $3.00+0.05$ & $2.00+0.00$ &
\end{tabular}

(Extract-100 $\mu \mathrm{g} / \mathrm{ml}$; Period of incubation-24 h; Positive control-Cefotaxim-100 $\mu \mathrm{g} / \mathrm{ml}$ (Antibiotic) Negative control-Methanol; Well diameter-5 mm. Each value represented as mean, $n=3$ )

\section{DISCUSSION}

The responses of in vitro culture analysis indicated that 2,4-D was the best auxin in combination with BAP as regards callus induction. In earlier studies, 2,4-D was reported to be an effective growth hormone that produced rapid proliferating friable callus in Curcuma amada [15], Gymnema sylvestris [16] and Brassica napus [17] during in vitro cultures.

Relatively lesser level of phytochemicals in callus can be interpreted as follows. Callus being an undifferentiated meristematic tissue accumulates only minor quantity of plant secondary metabolites. However, in general, the majority of callus and suspension cultures produce lesser quantities of secondary metabolites. This is mainly due to the lack of fully differentiated cells in the cultures.

In the present study, no alkaloids and tannins were detected in callus samples but these were found in samples from cultivated plants. The absence of alkaloids and tannins in callus tissues could be explained as due to lack of cellular differentiation and organogenesis in undifferentiated tissue like calli. Accumulation and storage of secondary metabolites such as alkaloids and tannins 
might be associated with organogenesis. Differentiated plant parts such as leaves, stem and roots normally serve as effective storage centres of these phytoconstituents. The observations of the present study agree with an earlier report on comparative phytochemical yield in wild and in vitro derived tissues of Harpagophyllum procumbens [18].

The correlation between age of culture and accumulation of natural product may possibly be due to the reason that secondary metabolites accumulated in the later stage when the growth of callus slow down. Enhancement in yield of secondary metabolites with the age of the callus has been reported for the accumulation of cryptotanshinone in Salvia miltiorrhiza [19]. In Morinda citrifolia also chemical constituents accumulate in the later stage of growth cycle when growth slows down [20].

The phenolics and flavonoids are characterized by their potential to act as antioxidants. Flavonoids are oxidized by radicals resulting in a more stable, less reactive radical. It appears that the flavonoids stabilize the reactive oxygen species (ROS) by reacting with the reactive compound of the radical [21]. In general, a positive correlation exists between antioxidation capacities and total polyphenol and flavonoid contents. Earlier reports on the antioxidant potential of Ulva prolifera [22] and Garcinia species [23] confirmed this correlation. In the present study also, a strong positive correlation was documented between total phenolic and flavonoid content and antioxidant capacity. The results suggested that wild grown plant with comparatively higher concentrations of secondary metabolites could exhibit maximum DPPH scavenging ability than the callus. The current observations were in agreement with the reports of Bouba et al. [24], where a positive correlation between total phenolics and flavonoids and antioxidant profile in extracts of Cameroonian spices was reported. Similar observations have also been reported by Chai and Wong [25].

The present study indicated that all extracts of Trichosanthes cucumerina (L.) var. cucumerina were potent against the Grampositive strain (Staphylococcus aureus) than the Gram-negative bacteria (scherichia coli and seudomonas aeruginosa). These results are similar and consistent with reports on related plant extracts which reported inhibition zone sizes varying from $7 \mathrm{~mm}$ for Pseudomonas aeruginosa to $33 \mathrm{~mm}$ for Staphylococcus aureus [26$31]$. It could be explained on basis of the inherent properties that are related to the composition of cell wall architecture and cell surface permeability to the extracts tested. The antibacterial activity of these extracts could be correlated as due to the presence of secondary metabolites such as flavonoids, phenolic compounds, terpenoids, tannin and alkaloids that adversely affect the growth and metabolism of microbes. The comparatively poor antibacterial profile indicated by the callus extract which contains no alkaloids and tannin supports this correlation.

\section{CONCLUSION}

A comparative evaluation of phytochemicals in extracts from naturally propagated and in vitro derived plant parts suggested that Trichosanthes cucumerina (L.) var. cucumerina is a rich source of biologically active phytoconstituents. All samples compared exhibited moderate to high level of antioxidant and antibacterial potential and substantiated its medicinal uses. Results of in vitro culture indicated that this highly valued medicinal species with poor seed longevity could be successfully regenerated in artificial media and this could be suggested as a remedial measure to counteract the occasional failure in natural seed germination.

\section{ACKNOWLEDGEMENT}

The authors gratefully acknowledge the Principal, University College, Thiruvananthapuram for all laboratory facilities.

\section{AUTHORS CONTRIBUTION}

The first author (Sudha Bai R): Conception and design of the project, data interpretation and manuscript preparation.

The second author (Remakanthan A): Planning and layout of experiments on in vitro culture.
Third author (Hareesh Kumar H): Conducted experiments on in vitro culture, antibacterial study and data acquisition.

Fourth author (Aryakrishna U K): Conducted experiments on phytochemical evaluation, antioxidant assay and data acquisition.

\section{CONFLICT OF INTERESTS}

\section{Declare none}

\section{REFERENCES}

1. Doriskumadoh, Kwabena Ofori-Kwakye. Dosage forms of herbal medicinal products and their stability considerations-an overview. J Crit Rev 2017;4:1-8.

2. Warrier PK, Nambiar VPK, Ramankutty C. Indian medicinal plants compendium of 500 species. (Orient Longman Pvt. Ltd. Chennai); 2000. p. 320.

3. Singh KP, Singh RH. Clinical investigation of the importance of Trichosanthes dioica. J Res Ayurveda Siddha 1985;6:132-40.

4. Sandhya S, Vinod KR, Chandra Sekhar J, Aradhana R, Nath VS. An updated review on Trichosanthes cucumerina L. Int J Pharm Sci Rev Res 2010;1:56-60.

5. Mbaebe BO, Edeoga HO, Afolayan AJ. Phytochemical analysis and antioxidant activiyies of aqueous stem bark extract of Schotia latifolia Jacq. Asian Pac J Trop Biomed 2012;2:118-24.

6. Meenakshi S, Umayaparvathi S, Arumugan M, Balasubramanian T. In vitro antioxidant properties of FTIR analysis of two sea weeds of gulf of Mannar. Asian Pac J Trop Biomed 201;1(Suppl 1):S66.

7. Harbone JB. Methods of plant analysis. In. Phytochemical Methods. (Chapman and Hill. London); 1973. p. 4-16.

8. Singleton VL, Rossi JA. Colorimetry of total phenolics with phosphomolybdic-phosphotungstic acid reagents. Am J Enol Vitic 1965;16:144-58.

9. Zhishen Y, Meugcheng T, Jianming W. Determination of flavonoid content in mulberry and their scavenging effect on superoxide radicals. Food Chem 1999;64:555-9.

10. Okwu DE. Phytochemicals, vitamins and mineral contents of two nigeria medicinal plants. Int J Mol Med Adv Sci 2005;1:375-81.

11. Blois MS. Antioxidant determination by the use of a stable free radical. Nature 1958;29:1199-200.

12. Banerjee D, Chakrabarti S, Hazra AK, Banerjee S, Ray J, Mukherjee B. Antioxidant activity and total phenolics of some mangroves in sundarbans. Afr J Biotechnol 2008;58:1407-10.

13. Perez C, Pauli M, Bazerque P. An antibiotic assay by the agarwell diffusion method. Acta Biol Med Exp J Med Biol Sci 1990;15:113-5.

14. Hewitt W, Vincent S. Theory and application of microbiological assay. Eds. Academic Press: San Diego; 1989. p. 39.

15. Prakash S, Elangomathavan R, Seshadri S, Kathiravan K, Ignacimuthu S. Efficient regeneration of Curcuma amada Roxb plantlets from rhizome and leaf sheath explants. J Plant Cell Tiss Org Cult 2004;78:159-65.

16. Roy A, Ghosh S, Chaudhuri M, Saha PK. Effect of different plant hormones on callus induction in Gymnema sylvestris $\mathrm{R}$. Br. (Asclepiadaceae). Afr J Biotechnol 2008;7:2209-2211.

17. Jonoubi P, Mousavi A, Majd A, Salmanian AH, Jalali J. M. Efficient regeneration of Brassica napus L. hypocotyls and genetic transformation by Agrobacterium tumefaciens. Biol Plantarum 2005;49:175-80.

18. Bairu MW, SO Amoo, J Van Sladen. Comparative phytochemical analysis of wild and in vitro derived greenhouse-grown tubers, in vitro shoots and callus-like basal tissues of Harpsgophyllum procumbens. South Afr J Bot 2011;77:479-84.

19. Tsay HS, Agrawal DC. Tissue culture technology of Chinese medicinal plant resources in Taiwan and their sustainable utilization. Int J Appl Sci Eng 2005;6:121-40.

20. Hagendoorn MJM, Jamar DCL, Meykamp B, Plas LHW. Cell division versus secondary metabolites production in Morinda citrifolia cell suspension culture. J Plant Physiol 1997;150:325-30.

21. Nijveldt RJ, Van Nood E, Van Hoorn DEC, Boelens PG, Van Norren K, Van Leeuwen PAM. Flavonoids: a review of probable 
mechanisms of action and potential applications. Am J Clin Nutr 2001;74:418-25.

22. Liu CC, Zhao GL, Li YN, Ding ZP, Liu QG, Li JL. The contribution of phenolics and flavonoids to the antioxidant activity of ethanol extract from Eichhornia crassipes. Adv Mat Res 2010;156-157:1372-7.

23. Nabajyoti Gogoi, Ankur Gogoi, Bijoy Niyog. Free radical scavenging activities of Garcinia xanthochymus Hook. F. and Garcinia lanceaefolia Roxb. using various in vitro assay models. Asian J Pharm Clin Res 2015;8:138-41.

24. Bouba A, Njintang YN, Scher J, Mbofung CMF. Phenolic compounds and radical scavenging potential of twenty Cameroonian spices. Agric Biol J North Am 2010;1:213-24.

25. Chai TT, Wong FC. Whole-plant profiling of total phenolic and flavonoid contents, antioxidant capacity and nitric oxide scavenging capacity of Turnera subulata. J Med Plant Res 2012;6:1730-5.

26. Mansouri S, Foroumadi A, Ghaneie T, Ahmad GN. Antibacterial activity of the crude extracts and fractionated constituents of Myrtus communis. Pharmaceutical Biol 2008;39:399-401.
27. Thaniarasu $\mathrm{R}$, Senthilkumar $\mathrm{T}$, Abubacker MN, Rao MV. Preliminary phytochemical screening and evaluation of antibacterial activity of different solvent extracts of Plectranthus bourneae Gamble. (Lamiaceae). Asian J Pharm Clin Res 2015;8:79-82.

28. Ndukwe IG, Amupitan JO, Isah Y, Adegoke KS. Phytochemical and antimicrobial screening of the crude extracts from the root, stem bark and leaves of Vitellaria paradoxa. Afr J Biotechnol 2007;6:1905-9.

29. Soumya Menon, Happy Agarwal, S Rajeshkumar, S Venkat Kumar. Green synthesis of silver nanoparticles using medicinal plant Acalypha indica leaf extracts and its application as an antioxidant and antimicrobial agent against foodborne pathogens. Int J Appl Pharm 2017;9:42-50.

30. Goyal P, Khanna A, Chauhan A, Chauhan G, Kaushik P. In vitro evaluation of crude extracts of Catharanthus roseus for potential antibacterial activity. Int J Green Pharm 2008;2:176-81.

31. Raghavendra HL, Prashith Kekuda TR, Karthik KN, Ankith GN. Antiradical, the antibacterial and antifungal activity of Harpullia arborea (blanco) radlk. (sapindaceae). Int J Curr Pharm Res 2017;9:32-6. 